\title{
Forum
}

PMLA invites members of the association to submit letters that comment on articles in previous issues or on matters of general scholarly or critical interest. The editor reserves the right to reject or edit Forum contributions and offers the PMLA authors discussed in published letters an opportunity to reply. Submissions of more than one thousand words are not considered. The journal omits titles before persons' names and discourages endnotes and works-cited lists in the Forum. Letters should be doublespaced if printed and be addressed to PMLA Forum, Modern Language Association, 26 Broadway, 3rd floor, New York, NY 10004-1789 (pmlaforum@mla.org).

\section{An Auden Variant}

\section{To THE EDITOR:}

It's surprising that Stephen E. Severn's article "The Library of Congress Variant of 'The Shield of Achilles'” (124.5 [2009]: 1761-67), so earnestly devoted to explaining in detail a variant word in a handwritten copy of a poem, should misquote four lines about which there is no dispute. Auden's "unintelligible multitude" in "The Shield of Achilles" is here assembled on a "plane without feature, bare and brown" (1762). How could a million "eyes" and "boots in line" possibly fit, much less stand, on that brown plane-or in it? And why is it "bare"? The line, of course, should read (and does in all editions), "A plain without a feature...."

The next sentence tells us that this formidable host is "awaiting a sign," which is not, I feel sure, what any version of Auden's poem says; his phrase is "waiting for a sign." Besides showing carelessness about details in an essay purporting to argue how great a difference one small change of wording can make to a poem, these gaffes suggest an imprecision about matters dear to Auden's heart, for both misquotations (in metrically regular stanzas) render the lines in question metrically anomalous. As an old scholar much indebted to PMLA, I can't help wondering whether anyone these days-authors, readers, or editorscan still hear verse lines as verse. More plainly, why didn't anyone catch these mistakes?

And a further cavil: why not print the word "Proved" in the article's next line as "Proved"? Instead, we are given this bizarre substitute:

$[\mathrm{p}]$

roved....

Auden would be appalled at this way of reproducing his line. Still later, the quoted line "Whose logic brought them somewhere else to grief"

(C) 2010 BY THE MODERN LANGUAGE ASSOCIATION OF AMERICA 
fails to set off "somewhere else" with commas, as Auden did, and his commas alter the meaning. Compared to all these distortions, Auden's change of "some" to "no" seems small potatoes.

Yet even the rest of the argument makes little sense. Auden's poem strongly suggests that whatever the "voice without a face" is claiming is a lie. If it's proving that some cause is just or that no cause is just, what it says is a lie. Severn seems to think otherwise, that we should believe the voice. All Auden's work makes clear his utter contempt for dictators of the kind implied here, who drive credulous citizens or persecuted victims to their destruction. It doesn't matter much whether the disembodied voice is rallying people to some cause for which it is recruiting them to fight or mocking them for putting their faith in any cause. Auden may, in copying the poem, have leaned toward the second view and written "no." Both readings show the cynical malevolence of the tyrant.

George T. Wright

University of Minnesota, Twin Cities

\section{To THE EDITOR:}

In his interesting and instructive speculations on a variant reading in a fair-copy manuscript of Auden's “The Shield of Achilles," Stephen E. Severn argues that the variant resulted from a deliberate authorial act. But it also seems possible that it resulted from a common scribal error known as an eye-skip.

As Severn observes, all printed texts of the poem have this reading: "Out of the air a voice without a face / Proved by statistics that some cause was just." The fair-copy manuscript that Auden made to be sold at a charity auction in 1960 (seven years after he wrote the poem) re- places "some cause was just" with "no cause was just."

The manuscript is otherwise almost identical to the printed versions, so it seems likely that Auden prepared it by copying from a book that was open on his desk. The two lines that immediately follow the lines quoted above are these: "In tones as dry and level as the place: / No one was cheered and nothing was discussed...." The phrase that Auden miscopied ("some cause was just") has the structure "some $x$ was $y$." While he copied it, Auden's eye or memory may have skipped ahead two lines to the phrase "No one was cheered," which has the similar structure "no $x$ was $y$." Auden may have anticipated the "no $x$ was $y$ " structure of this second phrase while retaining the $x$ and $y$ of the first phrase ("cause" and "just"). The result would be the miscopied phrase in the manuscript: "no cause was just."

Of course, this suggestion contradicts none of Severn's speculations. Even a simple scribal error may have had complex motives behind it-or it may have been nothing more than an eye-skip.

Edward Mendelson

Columbia University

\section{Sexual Victims of War}

\section{To THE EDITOR:}

An entire issue of PMLA on the topic of war (124.5 [2009]) and not one prostituted voice anywhere? One of the most important aspects of war-the turning of the vulnerable into "comfort women"-and you completely ignore this terrible sexual atrocity?

Name withheld 